\title{
E-Learning Theories, Components, and Cloud Computing-Based Learning Platforms
}

\author{
Vikas Kumar, Chaudhary Bansi Lal University, Bhiwani, India \\ (iD) https://orcid.org/0000-0002-6753-1557 \\ Deepika Sharma, Jagannath University, Jaipur, India
}

\begin{abstract}
The student habit of using the digital platforms can be used to compliment the traditional learning methods. Specifically, designed digital learning platform can support the learning with convenience of time, place, and pace. They can increase the engagement of students and produce higher learning outcomes with increased satisfaction and competence. With a number of embedded features, cloud computing technology-based platforms can deliver the convenience and flexibility in learning environment to compliment the traditional learning pedagogies. The present work identifies the essential learning components that comprise the e-learning environment and categorizes them according to the established learning theories. Further, the prominent cloud-based learning platforms have been mapped to these platforms to see their effectiveness through the existing theories. The work is targeted to form a basis for the development and implementation of successful e-learning tools using the cloud-based platforms.
\end{abstract}

\section{KEYWORDS}

Cloud Computing, Convenience, E-Learning, Motivation, Social-Constructivist

\section{INTRODUCTION}

Learning is a recursive process and it involves the creating reading, analyzing, practicing and improving the knowledge contents in a consistent manner. Digital tools came into existence to have more impact on the learning process and improving the learning outcome (Kumar and Sharma, 2016). Learning using the digital tools is referred as e-learning and this kind of learning creates a higher impact on educational practices by connecting learners to each other (Siemens, 2005). Siemens theory of connectivism emphasized the integration of technology during learning. It also asserts on providing a collaborative environment for interaction and participation of learners in social environment (Siemens, 2005). E-learning environment gives flexibility, personalization and customization in learning styles to improve learning outcomes (Jethro et al., 2012). It has the most cited advantage of learning delivery; including the increased accessibility to information, ease of content updating 
and distribution, personalization of instructions, standardization of content, and accountability. In E-learning, learners get a lot of flexibility to choose the learning sequence time and pace of learning. This can also support a mechanism to achieve the personal learning objectives of learners through a self-tailored approach.

There are many benefits of e-learning that facilitate the learning process (Bouhnik \& Marcus, 2006; Liaw et al., 2007a; Raab et al., 2002). E-learning uses network technologies to create, foster, deliver, and facilitate learning, on anytime and anywhere basis (Alonso et al., 2005). It creates a good environment for communication and pedagogy based interaction between students and instructors (Bermejo, 2005; González-Videgaray, 2007, Kumar and Nanda, 2020). It may also assist in better bonding between the teacher and student by delivering a collaborative digital workspace. This can lead to improved quality of learning by providing collaboration and access to resources and services (Alonso et al., 2005), digital content delivery, network based support of teacher (Markus (2008). Valuable insights of student engagement can be measured by analyzing this collaboration (Kumar and Nanda, 2019).

However, a number of learning theories and pedagogies already exist and they have proven their effectiveness and impact in various contexts. Specific learning pedagogy must be followed to have effective outcome based learning. On the other hand, an established pedagogical approach may deliver good educational practices to motivate and engage students, which can further lead to better learning outcomes. Hence, a structured process is required to integrate the learning theories, practical pedagogies and the available technologies. To explore these components of e-learning process, a careful analysis of e-learning theories is required to gain granular and fine insights of learning. Correspondingly, e-learning literature has been reviewed in the following section to identify the various theoretical perspectives.

\section{E-LEARNING THEORIES AND COMPONENTS}

E-learning is important for building a technologically literate workforce as well as for meeting society's continuous need for rapid life-long learning delivered in increasingly more convenient forms (Nycz \& Cohen, 2007; Buzzetto -More, 2008). According to Kandies and Stern (1999), web enabled learning environment provide active and self-directed learning with enhanced learning materials. E-learning is underway of its $3^{\text {rd }}$ generation, incorporated by socialization, collaboration, project based learning, reflective practices via tools like wikis, blogs, portfolios, social bookmarking and networking, and online simulations (Connolly and Stansfield, 2007; Buzzetto, 2008). E-learning systems incorporate technology, pedagogy and individuals to achieve effectiveness (Fuller, Vician, and Brown, 2006). Learning facilitated by technologies, transforms the concept of teaching and learning (Buzzetto-More, 2008; Koohang \& Harmon, 2005; Lewis et al., 2005). It redefines the role of a teacher and transforms the meaning and content of the learning process. Learning moves from a Tayloristic or behavioristic linear model towards a more constructivist approach. Constructivist approach is fostered by web-based instruction, where learning is a more authentic and self-directed experience.

Lee (2008) identified the several factors, which influence e-learning adoption beside perceived usefulness and ease of use. E-learning delivers learner-centered, personalized, flexible, individual, self-organized, collaborative learning based on a community of learners, teachers, facilitators, experts (Jethro et al., 2012). E-learning in a networked society considers personalization, participation, and productivity (McLoughlin \& Lee, 2008) as three dimensions. E-learning provides increased accessibility to information, ease in updating content, personalized instruction, ease of distribution, standardization of content, and accountability with tracking activities of learners that reduces faculty and administrative burden (Jethro et al.,2012; Ozkan \& Koseler, 2009). E-learning systems also benefit the stake-holders through located standardization, accountability, on-demand availability, self-pacing, interactivity, confidence, and increased convenience. E-learning reduces costs while consistently delivering content, with improved tracking (Welsh et al., 2003). 
E-learning environment should incorporate four elements: environmental characteristics, environmental satisfaction, learning activities, and learner characteristics (Liaw \& Huang, 2007). In environmental characteristics, the interaction will create a high-level communication between the students that enhance the participation in the learning process. The interaction of learners during e-learning activities will promote the share of knowledge and experience between instructor and students. The creative and active learning environment will create students satisfaction for e-learning. This interaction will support students to build their own knowledge in social environment (Liaw et al., 2007b). The Kirkpatrick model of training provides four levels of evaluation: satisfaction, learning, change in learner behaviour and results or outcome of training (Bates, 2004). Student satisfaction (Liaw et al., 2007b) and training outcome is important to measure training effectiveness (Douglas \& Vyver, 2004) with the student experience (Gilbert, 2007). According to Bandura (1986), human behaviour is influenced by desired outcome and self-efficacy. Self-efficacy refers an individual's belief in their own abilities (Bandura, 1986), while outcome refer to an individual's belief that he/ she will receive a result after completing a particular task (Henry \& Stone, 1994).

The attitude of learner, quality of instructor, quality of system and information (content), quality of service, and support are important factors for learners satisfaction (Ozkan \& Koseler, 2009). The student's attitude towards learning process needs inclination and this inclination for achieving goals is a good motivation towards learning. According to Bhuasiri et al. (2012), motivation is the extent to which persistent effort is directed toward a goal. The intrinsic motivation (Davis, Bagozzi, \& Warsha, 1992) and extrinsic motivations (Roca \& Gagne, 2008) are measured for learners and instructors in e-learning process. Intrinsic motivation comes with interesting activities and extrinsic motivation relates to doing activities for result or outcome (Ryan \& Deci, 2000; Vallerand, 2000; Meyer \& Gagne, 2008). Some intriguing ideas can play significant role in learning and motivation in classrooms (Pintrich, 2003). According to Govidaswamy (2002), e-learning includes seven factors: student support, institution support, faculty support, teaching and learning, course structure, evaluation and assessment. Learning enhancement permits greater learner interactivity and promotes learners efficiency, motivation, cognitive effectiveness, and flexibility of learning style (Jethro, 2012).

NAHE report (Ossiannilsson \& Landgren, 2012) is based on holistic approach of e-learning by considering ten quality aspects: material/content, structure/virtual environment, communication, cooperation and interactivity, student assessment, flexibility and adaptability, support (student and staff), staff qualifications, vision and institutional leadership resource allocation and the holistic and process aspect. The e-learning critical success areas in existing benchmark of pick and mix model includes accessibility, reliability, eco-sustainability, employability, e-portfolios integration services; staff and students learning material, library services e-resources organizational learning, pedagogy, personalization, plagiarism (formerly plagiarism avoidance), quality assurance, staff recognition and rewards, widening participation.

Later on Lund University added few more success areas for e-learning: constructive, democratic processes, flexibility, interactiveness, legal security, participation, productivity and transparency.

Various researchers and analyst gave different aspects regarding elearning pedagogy.

By analyzing the theoretical perspective of e-learning pedagogy the following characteristics have been derived for a successful e-learning framework:

1. learner centered

2. eco-sustainability

3. socio-economic/cost -effectiveness

4. connectivity /Networking

5. increased accessibility

6. on demand availability

7. interaction

8. participation 
9. cooperation

10. collaboration

11. motivation

12. engaging

13. communication

14. intrinsic motivation

15. extrinsic motivation

16. intriguing ideas

17. self determination

18. competence

19. autonomy

20. relatedness

21. cognitive effectiveness

22. convenient

23. reliability

24. efficiency

25. achievement

26. personalization

27. self-pacing

28. constructive alignment

29. higher learning outcome

30. learner-satisfaction

31. confidence

32. peer-review

33. evaluation /assessment /feedback from instructors

34. improved tracking

35. flexibility

36. skills and knowledge improvement

37. learner satisfaction

These characteristics can be further divided, according to the four major learning theories : 1) Cognitive theory 2) Social Constructivist theory 3) Motivation Theory 4) E-learning theory. The categorisation has been shown in Table 1 .

Components of e-learning are present in many digital learning platforms available today and cloud computing technology has come up a long way to support these digital learning platforms. Many cloud based digital learning platforms are available in the market. Cloud computing technology provides scalable and flexible technical infrastructure capabilities as an on-demand service (Singh $\&$ Kumar, 2014). The users can access cloud computing resources from any place, anywhere and at anytime via any mobile computing devices such as laptops, mobiles, tablets or smart phones. Cloud computing provides its services in cost effective manner without the need to install and update of software and hardware (Shibi et al., 2013). Cloud computing provides collaborative online learning environment to assist learner community for active participation (Shuangquan, 2010). The cloudbased collaborative learning environment motivates the learners to work in a team and improve their thinking capabilities (Sharma and Kumar, 2017).

\section{CLOUD COMPUTING BASED E- LEARNING PLATFORMS}

Cloud computing can offer a lot of advantages to the teaching learning process by offering convenience and collaboration in a very cost-effective manner (Nayar and Kumar, 2018). A number of cloud based e-learning platforms have been emerged in the recent years and these can offer more participation 
Table 1. e-learning components categorised on Learning Theories

\begin{tabular}{|l|l|l|l|}
\hline \multicolumn{1}{|c|}{ Cognitive theory (CT) } & \multicolumn{1}{|c|}{$\begin{array}{c}\text { Social Constructivist theory } \\
\text { (SCT) }\end{array}$} & Motivation theory (MT) & \multicolumn{1}{c|}{$\begin{array}{c}\text { E-learning Theory } \\
\text { (E-LT) }\end{array}$} \\
\hline Learner -Satisfaction & Collaboration & Motivation & Learner Centered \\
\hline Higher Learning Outcome & Interaction & Intrinsic Motivation & Eco-Sustainability \\
\hline Cognitive Effectiveness & Participation & Extrinsic Motivation & $\begin{array}{l}\text { Socio-Economic/Cost } \\
\text {-Effectiveness }\end{array}$ \\
\hline Individual Learning & Cooperation & Intriguing Ideas & $\begin{array}{l}\text { Connectivity / } \\
\text { Networking }\end{array}$ \\
\hline Personalization & Engaging & Self Determination & Increased Accessibility \\
\hline Achievement & Communication & Competence & $\begin{array}{l}\text { On Demand } \\
\text { Availability }\end{array}$ \\
\hline Self-Efficacy & Constructive Alignment & Autonomy & Convenient \\
\hline Efficiency Improvement & Peer-Review & Relatedness & Flexibility \\
\hline $\begin{array}{l}\text { Skills And Knowledge } \\
\text { Improvement }\end{array}$ & $\begin{array}{l}\text { Evaluation /Assessment / } \\
\text { Feedback }\end{array}$ & Confidence & Self- Pacing \\
\hline & & & Improved Tracking \\
\hline
\end{tabular}

and enthusiasm in the classroom. Many of them have derived their effectiveness from the traditional pedagogies, whereas many are based on the recent technological applications. The adoption of cloudbased software in their regular classroom will support students to enrich their self-efficacy, confidence and ability by accelerating engagement and the learning outcomes. The cloud based platform provide collaborative network to teachers and students, where peer to peer participation and interaction will provide higher engagement to the students (Kumar and Sharma, 2016). Teachers can create and share their lessons in single digital workspace by keeping all resources at one location. This will speeds up the day to day work in organized manner that helps students and teachers in consistent learning. The cloud-based teaching and learning tools incorporate intuitive analytics to measure student performance and learning outcomes. The analytics allows teachers to gain student insight, engagement, interaction and contribution in the social environment. Such type of information will assist teachers to their regular efforts to upgrade and motivate students with increased productivity. The students will develop cognitive enhancement and competence after practicing with these tools.

Cloud based learning platforms can be categorised on the basis of supporting cognitive, socialconstructivist, motivation and e-learning theories. These platforms support the learning theories through some specific features and may miss some of the other vital parameters of these theories. Mapping of cloud-based digital learning platforms with the learning theory components will assist in analysing these platforms for supporting learning theory pedagogy. The pedagogical approach of cloud-based learning platforms will deliver complete benefit to learning community in education at different levels (Kumar and Bhardwaj, 2020). Entire learning community may be benefited by implementation of cloud-based learning platforms in their campus premise. The most prominent cloud based learning platforms include:

\section{Google Educational Cloud ( https://www.google.com/edu/ )}

Google Educational App Suite provides virtualized collaborative learning environment. It integrates Google Classroom, Google Gmail, Google documents, Google Calender, Google drives, Google Sites to support teachers and learners for personalized environment with ease to operate and 
manage functionalities. Google provides education apps with full security at free of charge. Google classroom provides collaborative working environment to students and teacher (Huang et al., 2013). Google apps deliver online collaborative word processing, worksheet and presentations with cloud storage space. It also provides blogs, forums, Google maps and google earth services. Students can upload their assignments, which are further reviewed and monitored by teachers. Google classroom and online collaborative modules supports all the components of social constructivism theory. The platforms that follow the social constructivist theory pedagogy will in turn delivers motivational and cognitive components. Hence it supports the motivation and cognitive theory pedagogy as well. Thus, Google educational apps follows all the four learning theory pedagogies completely.

\section{Microsoft Education Cloud ( https://www.microsoft.com/ )}

Microsoft Education Cloud facilitates students to enhance their skills by communicating, collaborating and problem solving. It empowers the teachers and students with free email, web sites, online document editing, messaging and web conferencing applications. Students can create online documents with their classmates and keep up to date with shared notebooks. It provides online power point, excel, power map, collaboration with other students with the facilities of office online. Microsoft OneNote makes it easy to plot graphs in 2D and 3D and also to simplify the algebraic expressions. One note class notebooks provides personal web space for every student, a content library for handouts and collaboration space for lessons and teamwork. Students can easily collaborate on new Sway app to create assignments, projects, study materials. Sway assist teachers to create interactive web based lessons, assignments and projects.

Pulse in the classroom product of the Education cloud, supports the engagement in classroom in a simple, fast and fun manner. Teachers can gain real time response from the students for understanding the lessons or modules. Teachers will get immediate response through pulse. Teachers can create groups among students for more interaction and fun during class. By using pulse product, students can track their performance as a team. Microsoft education supports the various learning theory. However, being a commercial product, it partially supports the E-learning theory.

\section{Moodle ( https:/moodle.org/)}

Moodle platform is very much popular among learner community as its pedagogical approach is based on social constructionist pedagogy. Moodle supports the sound pedagogical principles to help educators to create very effective online learning environment (Kozaris, 2010). This is very userfriendly and flexible product, which is available as an open-source product all over the world (Al-Ajlan, 2012). A study conducted by Cole (2007) shows that Moodle is the best learning management system for learning framework in higher education as it has strong documentation, administration and security support. Moodle can work with wide range of database systems and assists in installing, administering and using the LMS (Steel \& Levy, 2009). According to eLearning Guild research, Moodle is ranked as the top LMS product among 100 professionally -developed LMS products (Davis et al., 2009). Moodle provides tools to assess user level of engagement and learning status (Mazza et al., 2012). Instructors can evaluate the activity execution by individual student and points to improve the learning areas. The teachers can create structured and organised lesson plans while making slides, providing text documents, web links and links to simulation of labs (Komninou et al., 2012).

\section{Blackboard ( https://anz.blackboard.com/ )}

Blackboard provides learning management system focused on integrating social learning with personalized learning experience. It provides virtual learning environment by integrating Blackboard 
Learn, Blackboard Collaborate, and Blackboard Analytics along with its mobility services. Blackboard Learn flourishes engaged learning and efficient teaching model. It assists in access for assignments and updating for various dates and events in learner community through collaborative spaces. Students can create rich digital content with peer contributions from various resources and share with each other. Blackboard Collaborate will create a real-time collaborative platform for students and teachers with its mobility features. It has a web conferencing feature as well to support the teaching and learning environment Blackboard ConnectTxt is a real time SMS survey that eases the teachers to get students involved with their content. Blackboard will deliver higher learning outcomes, student satisfaction and improvement in knowledge and skills. Learners can connect to these resources from anywhere and at anyplace. Blackboard Analytics help to analyse the students performance. Teachers can provide real time feedback and grades. Blackboard analytics personalized dashboard assist individual learner to access their own portfolios. The response rate of any question asked by the students is very fast in Blackboard analytics. This gives intrinsic motivation to the learner with increased confidence and cognition. Blackboard follows various learning theories, however it only partially supports the E-learning theory, being a commercial product.

\section{Sakai ( http://sakaiproject.org/ )}

Sakai is one of the major open source providers for learning management system and is a big competitor of Moodle LMS. It gives access to Assignments, Test and Quizzes, Gradebook, Syllabus, Lesson builder with access to mobile services. It supports the peer review of lessons, prevents empty assignment submission by students, also provides the Forums tool that include performance improvement in Forums and Gradebook row highlighting for easier grading of students. Sakai facilitate teams to coordinate, collaborate, share resources, schedule activities and track activities progress. It also supports the project collaboration workspaces for learners and online assessment to provide valuable feedback to students. It allows chat, discussion, email, announcements to group, document sharing, storage and co-authoring and also facilitates the analysis of documents and data (Carmichael et al., 2006). Sakai is an open source digital learning system. It supports all learning theories completely.

\section{Cisco Collaborative Knowledge ( https://www.cisco.com/ )}

Cisco Collaborative Knowledge provides centralized learning management system to solve real time business challenges in clouds. It allows its users to work, collaborate and innovate with mobility features. It centralizes training, curriculum planning, event scheduling and administration. It integrates the real time collaboration tools to help in detecting the availability of other collaborators. It delivers training, social learning, peer validation, interaction through Webex and Jabber tools (https://www. cisco.com/c/dam/en/us/products/collateral/cloud-systems-management/collaborative-knowledge/ collaborative-knowledge-aag.pdf). Webex and Jabber tools provides the real time collaboration facility to connect users and peers by sharing videos, voice and data. Rating, ranking and reviewing the collaborative content can be done on this platform. Visual Knowledge map in Cisco collaborative knowledge system shows a visual representation of a individual mapping with reference to people, content and knowledge identities. The knowledge map reflects the strengths and gaps of areas, where knowledge can be improved. Analytics technology supports the real time feedback. Users can upload, store and organize knowledge assess in the digital library. Cisco collaborative knowledge supports various learning theories due to its present feature. It is a not an open source product, hence only partially supports the E-learning theory.

\section{Braidio Collaborative Learning Platform ( https://www.braidio.com/ )}


Braidio is a collaborative learning platform to foster learning by networking and collaboration. Braidio assist in developing talent of learners into daily routine by following a learning metrics. In Braidio platform: development of courses, management and assignment of courses and keeping track of the progress within the organization can be facilitated. Braidio learning tools provides collaborative learning space to foster sharing of contents and ideas among learners. Braidio delivers complete learning analysis and engagement of learners with built in tools for learning analytics. The conversation networking graph tracks the contents being discussed most in collaborative conversations. Braidio also support the community to work in a team environment towards a common goal. It engages the learner in collaboration, while sharing or contributing the content. This tools supports various learning theories, but being a paid product, it partially supports the E-learning theory.

\section{Echo 360 Active Learning Platform ( http://echo360.com )}

Echo360 is a learning management system that encompasses building notes, lectures, study guides and social learning into one digital workspace. Echo 360 empowers the modern classroom system, where students can collaborate and interact with each other. Learners can create classroom content with social learning environment, where resources are connected to each other at a single place. Students and teachers can interact with peer interaction and provide daily report with mobile device. Daily report metrics assist students and teachers to the measure performance levels and can identify gaps. Predictive analytics allows teachers to gain insights of student learning and provide real time instruction to improve. Teachers can find out the engagement of learner and find out the gaps. The gaps are maintained by delivering improvement strategy to students for retention. The Echo360 system analyzes student performance in courses, tracks their confusion on certain topics and monitoring note-taking, class participation, and collaboration among peers. Navigation between the classes, posting questions during the classes, responding to questions during the class, flagging and bookmarking content are its major features. Echo360 has a partnership with Cengage learning to increase participation and engagement of students for improved learning outcome. Students can take notes in context with video content (time stamped notes); ask and answer questions with peers; and respond via closed response and open-ended polls before, during and after class. Echo 360 tool follows the learning theories completely, but it is a paid product, hence it supports E-learning theory partially.

\section{N2N Illuminate Services Student Engagement Platform ( http://www.n2nservices.com/ )}

N2N Illuminate Services student engagement platform is an integrated campus with mobile communication facility. It is available as a Saas model of Enterprise Resource Planning system. It assists in communication between departments of campus. It integrates videos, webpages, and documents into lesson plans and allows integration of various data from variety of systems. It has admission module, Financial aid module, ID Card system module, social media, parking module and an integrated learning management system. It also embeds admission module, college communication and handles the student data. It incorporates workflow automation, predictive analytics and data visualization. $\mathrm{N} 2 \mathrm{~N}$ illuminate services integrates dashboard with it. Illuminate services of N2N is not a complete educational app. It has partial implication of various learning theories. Hence it is a partially supported learning platform.

\section{0. rSmart OneCampus ( https://www.rsmart.com/ )}

OneCampus is a digital workspace to enable students to discover various campus services such as class schedules, email through mobile friendly environment. One campus integrates the Google like search, rating and reviews, distributed publishing, multi-campus support, training and resources. 
It supports aggregate services for multiple campuses at one place. It gives institutional look and feel by adding logos, colors and style sheet to match brand. In training and resources modules receive support documentation and free upgrades. Students can check the frequent grades and announcements, dates and deadlines in their mobile phones using the One campus solution.Students can get ratings and reviews for continuous improvement. One campus is not a complete solution of educational app. It misses collaboration, interaction, motivation and participation. Hence, it partially supports the learning theories.

\section{WizIQ (https://www.wiziq.com/ )}

WIZIQ is a learning management system and provides virtual classroom with live and self-paced learning. It facilitates creation of test, video streaming with mobile friendly environment. Teachers can create hundreds of courses online by using creation wizard and can use the in-built assessment facility. Educational videos, slideshows, and animations for virtual classroom can also be created in this. Wiziq delivers collaborative application software for mutual team work by students and their peers. Wiziq allows online sharing and editing with word processing, power point presentation and spreadsheet. Students learn to work in collaborative teams. It incorporates live text and audio chat, through which students can post their questions and answers on the spot. It entails private chat feature, powerful whiteboard tools, integrated media player to stream videos. It provides content library upload and facilitates the interaction and assessment. It supports recording to help students in revision and to view the missed sessions. Though Wiziq facilitates certain very good features, it still lacks assessment analytics feature. It is concluded that Wiziq has partial implementation of E-learning theory.

\section{Engrade ( http://www.engrade.com/ )}

Engrade is a web based grading system for teachers, students and parents. Engrade is owned by Tata McGaw Hill. Engrade provides free set of tools for teachers to manage online classes. It integrates gradebook, calender, and wikis. It facilitates students and parents to keep track of information at any time in real time with mobility access feature to improve communication. Engrade delivers Instruct module for managing digital curricula and engaging interactive instruction, and Engrade Inform, provides assessments and tracking of students report online. It monitors the learning progress for each student in the classroom, schools with a powerful Data Wall visualization that captures student performance. Engrade delivers personalized learning experience to all users in the community. It sends and receives messages to parents and students, assign and grade homework from within Engrade. It delivers interactive learning tools such as game-based learning. Engrade is a very powerful tool that has all modern teaching tools. Still Engrade miss certain features such as collaborative project making and uploading and online assessment of assignment. Engrade learning platform partially supports the learning theories.

\section{Wiggio (http://www.wiggio.com/)}

Wiggio is a free tool to support social network and allows students or users to work in group. Wiggio integrates Host Virtual groups of person to schedule meetings and conference calls, assist in creating tasks and assigning tasks, sending voice messages, text and email, upload and manage files(docs and spreadsheet) in shared folder. The groups can share and work in online collaborative mode, where users can interact, participate and contribute to the document and save it in the cloud. It assists in managing event with calendar in sharing and polling group in real time. It supports to make group in academic activities such as sports, music/dance, committees, extracurricular, charities etc. The online assessment and monitoring feature is missing in Wiggio, hence it is partially supported 
with E-learning theory. In case, if any learning system lacks the feature of assessment analytics, it will automatically lose certain components of various learning theories. Hence Wiggio supports all learning theories only partially.

\section{Edmodo ( https://www.edmodo.com/ )}

Edmodo is an online collaborative workspace that offers tools for communication to teachers and students. Edmodo integrates the sharable content, assignment and home work. The teachers can distribute quizzes online to their students. Edmodo snapshot tools support for real time assessment to measure student performance. Feedback provides the insight of students learning path. It helps to identify the student lacking areas, where teachers can add suggestions. It assists in continuous learning environment. Edmodo uses the adaptive learning by personalizing the content. It facilitates customization and creation of content. Students can check their upcoming and due assignment. Edmodo facilitates classroom announcement as well as event reminders. Edmodo can be accessed from any device on total usage of edmodo tools by teachers and students. The real time interface is given to measure user engagement and adoption for the tools. Edmodo supports e-learning theory only partially, but it fully supports the other theories.

\section{Wikispaces ( https://www.wikispaces.com/ )}

Wikispaces is a social collaboration digital platform accessible via mobile services. It integrates wikispaces classroom to easily facilitate the real time collaboration between the teachers and students. Wikispaces provides assessment tools to measure student engagement, contribution and performance in real time. Wikispaces allows teachers to send feedbacks and assist the students. On the other hand, students can collaborate in teams for writing the projects. Wikispaces provides the tools to quickly and easily create assignments, share resources, make announcements, and foster discussion and community. Teachers can measure and monitor the real time contribution and engagement of students. The teachers can deliver real time feedback to students for assistance. Wikispaces can be accessed from any mobiles, browsers or tablets. Wikispaces classroom is free for students and teachers, however it has paid tools for schools and districts.

\section{Classdojo (http://www.classdojo.com )}

Classdojo is a digital workspace for teachers to encourage students, and share their best moments with parents. This can directly engage the parents. Classdojo integrates instant messages, announcements, uploading of photos and read receipts that directly reach the parents. Classdojo provides real time feedback about participation and engagement of students. Classdojo is free of cost for everyone. Students will kept track by accessing progress. It displays progress of students using GUI badges and icons for team work, on task, helping others, participation, leadership, curiosity, and working hard. Students responses are shown by using these icons to reflect their styles. Classdojo provides instant messages to parents and privately with direct messages. It shows announcements to the parents very quickly.

\section{Snapwiz ( http://www.snapwiz.com )}

Snapwiz is a collaborating learning space to create learning content and assigning it to the students. It provides personalized learning, interaction tools and analysis features that enhance student 
learning. Students get contextualized and adaptive texts, create and organize their study plan and participate in the live discussion with their classmates. It allows creating and grading assessment to give feedback to improve learning. Glider tool in snapwiz assists assessing and career planning app, effectively matches professionals with jobs based on skill competency. Glider provides multidimensional assessments ranging from programming languages to interpersonal skills to evaluate the candidate holistically. Teachers can create their own lessons and assignment for the students and share feedbacks for continuous improvement. It delivers Edulastic feature for interactive questionnaire sets based on drag and drop, graphing as well as passages. Students get a complete personalized and convenient learning environment.

\section{DocentEDU ( http://www.docentedu.com )}

Docent EDU is a free tool for the teachers to collaborate and participate in discussion in online mode. Docentedu integrates all essential ingredients including text, questions, discussions and guidance by teachers. Teachers can share their lessons with students in online mode. DocentEdu integrates google classroom, youtube, google sign-in and Google Docs. It gives security to the student data that is private. Private data is only visible to the students. Youtube videos urls can be added by pasting links in Docentedu. It is a completely free tool. It can be used by teachers and students. Teachers can get easy and efficient grading system by using DocentEdu.

\section{GoClass ( https://www.goclass.com )}

Goclass is a free, web-based collaborative digital space that integrates documents and presentations. Goclass provides space to create, edit and manage lesson plan by Show -ExplainAsk framework. It assists to add images, videos, teaching notes and assessment to lesson plan and uploading assignment. It delivers insightful dashboard and skill assessment to view progress of students. GoClass helps to improve student engagement, classroom management and effectiveness. Goclass enhanced instructor dashboard captures rich data around student performance and delivers this data in visual, easy-to-use snapshots that inform instruction \& help to manage tasks. Goclass has mobile feature, where contents can be sent to the student. Goclass+ enhanced instructor dashboard captures rich data around student performance and delivers this data in visual, easy-to-use snapshots that inform instruction \& help manage tasks.

\section{MAPPING THE LEARNING PLATFORMS AND LEARNING THEORIES}

The popular cloud based learning platforms are supporting the learning theories completely or partially. The platforms, which are supporting the different learning theories completely have been listed in the Table 2, whereas those supporting them partially have been listed in the Table 3 .

\section{CONCLUSION}

E-learning components, identified from the learning theories are very much important for any platform. If these components are not integrated in the platforms, the success of learning can-not be guaranteed. By analyzing various cloud-based digital learning platforms, it has been found that most of the platforms have a very close connection to the learning theories. The platforms have been specifically designed to take care of the particular objectives, considering the level and age group of students. With the inherent features of Cloud computing technology, Cloud-based learning 
International Journal of Web-Based Learning and Teaching Technologies

Volume 16 • Issue 3 • May-June 2021

Table 2. Cloud-based platforms supporting the four learning theories completely

\begin{tabular}{|c|c|c|c|}
\hline Cognitive Theory & Social Constructivist Theory & Motivation Theory & E-learning Theory \\
\hline Google educational Cloud & Google educational Cloud & Google educational Cloud & $\begin{array}{l}\text { Google educational } \\
\text { Cloud }\end{array}$ \\
\hline Moodle & Moodle & Moodle & Moodle \\
\hline Blackboard & Blackboard & Blackboard & Sakai \\
\hline Sakai & Sakai & Sakai & DocentEDU \\
\hline Microsoft Education Cloud & Microsoft Education Cloud & $\begin{array}{l}\text { Microsoft Education } \\
\text { Cloud }\end{array}$ & Goclass \\
\hline $\begin{array}{l}\text { Cisco Collaborative } \\
\text { Knowledge }\end{array}$ & Cisco Collaborative Knowledge & $\begin{array}{l}\text { Cisco Collaborative } \\
\text { Knowledge }\end{array}$ & Classdojo \\
\hline Braidio & Braidio & Braidio & \\
\hline Echo 360 degree & Echo 360 degree & Engrade & \\
\hline Edmodo & Edmodo & Edmodo & \\
\hline Wikispaces & Wikispaces & Wikispaces & \\
\hline Snapwiz & Snapwiz & Snapwiz & \\
\hline Classdojo & Classdojo & Classdojo & \\
\hline Docentedu & Docentedu & Docentedu & \\
\hline Goclass & Goclass & Goclass & \\
\hline Engrade & & & \\
\hline
\end{tabular}

Table 3. Cloud-based platforms supporting the four learning theories partially

\begin{tabular}{|l|l|l|l|}
\hline \multicolumn{1}{|c|}{ Cognitive Theory } & Social Constructivist theory & \multicolumn{1}{|c|}{ Motivation Theory } & \multicolumn{1}{c|}{ E-learning Theory } \\
\hline $\begin{array}{l}\text { Echo 360 Active Learning } \\
\text { Platform }\end{array}$ & $\begin{array}{l}\text { Echo 360 Active Learning } \\
\text { Platform }\end{array}$ & $\begin{array}{l}\text { Echo 360 Active Learning } \\
\text { Platform }\end{array}$ & $\begin{array}{l}\text { Echo 360 Active } \\
\text { Learning Platform }\end{array}$ \\
\hline $\begin{array}{l}\text { N2N Illuminate Services } \\
\text { Pludent Engagement }\end{array}$ & $\begin{array}{l}\text { N2N Illuminate Services } \\
\text { Student Engagement Platform }\end{array}$ & $\begin{array}{l}\text { N2N Illuminate Services } \\
\text { Student Engagement } \\
\text { Platform }\end{array}$ & $\begin{array}{l}\text { N2N Illuminate Services } \\
\text { Student Engagement } \\
\text { Platform }\end{array}$ \\
\hline rSmart OneCampus & rSmart OneCampus & rSmart OneCampus & rSmart OneCampus \\
\hline WizIQ LMS & WizIQ LMS & WizIQ LMS & WizIQ LMS \\
\hline Engrade & Engrade & Engrade & Engrade \\
\hline Wiggio & Wiggio & Wiggio & Wiggio \\
\hline & & & Braidio \\
\hline & & $\begin{array}{l}\text { Microsoft Education } \\
\text { Cloud }\end{array}$ \\
\hline & & & Cisco Collaborative \\
& & & Knowledge \\
\hline & & & Blackboard \\
\hline & & & Wnapwiz \\
\hline & & & \\
\hline
\end{tabular}


platforms will provide more participation and enthusiasm in the classroom. These platforms will facilitate teachers for quick communication with their students and groups, hence will motivate the learning process. Student cognition will also rise with the increased ability and capacity of individual students by delivering learning at anywhere, anytime basis. The pedagogically designed cloud based collaborative learning platforms will foster the deep rooted lifetime learning experience among the students. Hence, the Cloud based learning platforms will go a long way to improve the education standards, while keeping it simple, interesting and engaging. 


\section{REFERENCES}

Alonso, F., López, G., Manrique, D., \& Viñes, J. M. (2005). An instructional model for web-based e-learning education with a blended learning process approach. British Journal of Educational Technology, 36(2), 217-235. doi:10.1111/j.1467-8535.2005.00454.x

Bandura, A. (1986). Social foundations of thought and action: A social cognitive theory. Prentice Hall.

Baraka, N. A. (2012), A Web-Based Collaborative e-Learning Environment Based on a Model of Social Cognitive Development Theories (Doctoral dissertation). Islamic University of Gaza.

Bates, R. (2004). A critical analysis of evaluation practice: The Kirkpatrick model and the principle of beneficence. Evaluation and Program Planning, 27(3), 341-347. doi:10.1016/j.evalprogplan.2004.04.011

Bermejo, S. (2005). Cooperative electronic learning in virtual laboratories through forums. IEEE Transactions on Education, 48(1), 140-149. doi:10.1109/TE.2004.837045

Bhuasiri, W., Xaymoungkhoun, O., Zo, H., Rho, J. J., \& Ciganek, A. P. (2012). Critical success factors for e-learning in developing countries: A comparative analysis between ICT experts and faculty. Computers \& Education, 58(2), 843-855. doi:10.1016/j.compedu.2011.10.010

Bouhnik, D., \& Marcus, T. (2006). Interaction in distance-learning courses. Journal of the American Society for Information Science and Technology, 57(3), 299-305. doi:10.1002/asi.20277

Buzzetto-More, N. (2008). Student perceptions of various e-learning components. Interdisciplinary Journal of E-Learning and Learning Objects, 4(1), 113-135.

Carmichael, P., Rimpilainen, S., \& Procter, R. (2006). Sakai: a collaborative virtual research environment for education. In The annual conference of the B ritish Educational Research A ssociation (Vol. 629). University of Warwick.

Connolly, T., \& Stansfield, M. (2007). Developing constructivist learning environments to enhance elearning. In Principles of effective online teaching (pp. 19-38). Informing Science Press.

Davis, F. D., Bagozzi, R. P., \& Warshaw, P. R. (1992). Extrinsic and intrinsic motivation to use computers in the workplace. Journal of Applied Social Psychology, 22(14), 1111-1132. doi:10.1111/j.1559-1816.1992.tb00945.x

Douglas, E., \& Vyver, G. V. D. (2004). Effectiveness of e-learning course materials for learning database management systems: An experimental investigation. Journal of Computer Information Systems, 41(4), 41-48.

Fuller, R. M., Vician, C., \& Brown, S. A. (2006). E-learning and individual characteristics: The role of the computer anxiety and communication apprehension. Journal of Computer Information Systems, 46(4), 103-115. doi:10.1080/08874417.2006.11645917

Gilbert, J., Morton, S., \& Rowley, J. (2007). e-learning: The student experience. British Journal of Educational Technology, 38(4), 560-573. doi:10.1111/j.1467-8535.2007.00723.x

González-Videgaray, M. (2007). Evaluación de la reacción de alumnos y docentes en un modelo mixto de aprendizaje para educación superior. Relieve, 13(1) Retrieved from https://www.uv.es/RELIEVE/v13n1/ RELIEVEv13n1_4.htm

Govindasamy, T. (2002). Successful implementation of e-Learning pedagogical considerations. The Internet and Higher Education, 4(3-4), 287-299.

Henry, J. W., \& Stone, R. W. (1994). A structural equation model of end-user satisfaction with a computerbased medical information system. Information Resources Management Journal, 7(3), 21-33. doi:10.4018/ irmj.1994070102

Huang, L. N., Liu, F. H., \& Liu, C. L. (2013, October). Design and Research on Collaborative Learning Program Based on Cloud-services. Advanced Materials Research, 756, 1199-1203. doi:10.4028/www.scientific.net/ AMR.756-759.1199

Jethro, O. O., Grace, A. M., \& Thomas, A. K. (2012). E-Learning and its effects on teaching and learning in a global age. International Journal of Academic Research in Business \& Social Sciences, 2(1), 203-210. 
Kandies, J., \& Stern, M. B. (1999). Weaving the Web into the classroom: An evolution of Web enhanced instruction. Paper presented at the Teacher Education International Conference, San Antonio, TX. (ERIC Document Reproduction Service No. ED 432270)

Koohang, A., \& Harmon, K. (2005). Open source: A metaphor for e-learning. Informing Science Journal, 8, 76-86. Retrieved from http://inform.nu/Articles/Vol8/v8p075-086Kooh.pdf

Kumar, V., \& Bhardwaj, A. (2020). Role of Cloud Computing in School Education. In Handbook of Research on Diverse Teaching Strategies for the Technology-Rich Classroom (pp. 98-108). IGI Global. doi:10.4018/9781-7998-0238-9.ch008

Kumar, V., \& Nanda, P. (2019). Social Media in Higher Education: A Framework for Continuous Engagement. International Journal of Information and Communication Technology Education, 15(1), 109-120. doi:10.4018/ IJICTE.2019010107

Kumar, V., \& Nanda, P. (2020). Social Media as a Tool in Higher Education: A Pedagogical Perspective. In Handbook of Research on Diverse Teaching Strategies for the Technology-Rich Classroom (pp. 239-253). IGI Global. doi:10.4018/978-1-7998-0238-9.ch016

Kumar, V., \& Sharma, D. (2016). Creating Collaborative and Convenient Learning Environment Using CloudBased Moodle LMS. International Journal of Web-Based Learning and Teaching Technologies, 11(1), 35-49. doi:10.4018/IJWLTT.2016010103

Lee, Y.-C. (2008). The role of perceived resources in online learning adoption. Computers \& Education, 50(4), 1423-1438. doi:10.1016/j.compedu.2007.01.001

Lewis, B., MacEntee, V., DeLaCruz, S., Englander, C., Jeffrey, T., Takach, E., Wilson, S., \& Woodall, J. (2005). Learning management systems comparison. Proceedings of the 2005 Informing Science and IT Education Joint Conference. Retrieved from http://proceedings.informingscience.org/InSITE2005/P03f55Lewis.pdf

Liaw, S. S. (2008). Investigating students' perceived satisfaction, behavioral intention, and effectiveness of e-learning: A case study of the Blackboard system. Computers \& Education, 51(2), 864-873. doi:10.1016/j. compedu.2007.09.005

Liaw, S. S., \& Huang, H. M. (2007). Developing a Collaborative e-learning System Based on Users' Perceptions. Lecture Notes in Computer Science, 4402, 751-759. doi:10.1007/978-3-540-72863-4_76

Liaw, S. S., Huang, H. M., \& Chen, G. D. (2007 a). An activity-theoretical approach to investigate learners' factors toward e-learning systems. Computers in Human Behavior, 23(4), 1906-1920. doi:10.1016/j.chb.2006.02.002

Liaw, S. S., Huang, H. M., \& Chen, G. D. (2007 b). Surveying instructor and learner attitudes toward e-learning. Computers \& Education, 49(4), 1066-1080. doi:10.1016/j.compedu.2006.01.001

Markus, B. (2008, June). Thinking about e-learning. In Proceedings FIG International Workshop. Sharing Good Practices: E-learning in Surveying, Geo-information Sciences and Land Administration (pp. 11-13). Academic Press.

McLoughlin, C., \& Lee, M. J. W. (2008). The three P's pedagogy for the networked society: Personalisation, participation and productivity. International Journal on Teaching and Learning in Higher Education, 20, 10-27.

Meyer, J. P., \& Gagné, M. (2008). Employee engagement from a self-determination theory perspective. Industrial and Organizational Psychology: Perspectives on Science and Practice, 1(1), 60-62. doi:10.1111/j.17549434.2007.00010.x

Nayar, K. B., \& Kumar, V. (2018). Cost benefit Analysis of Cloud Computing in Education. International Journal of Business Information Systems, 27(2), 205-221. doi:10.1504/IJBIS.2018.089112

Nycz, M., \& Cohen, E. (2007). The basics for understanding e-learning. In Principles of effective online teaching (pp. 1-17). Informing Science Press.

Ossiannilsson, E., \& Landgren, L. (2012). Quality in e-learning-a conceptual framework based on experiences from three international benchmarking projects. Journal of Computer Assisted Learning, 28(1), 42-51. doi:10.1111/j.1365-2729.2011.00439.x 
Ozkan, S., \& Koseler, R. (2009). Multi-dimensional students' evaluation of e-learning systems in the higher education context: An empirical investigation. Computers \& Education, 53(4), 1285-1296. doi:10.1016/j. compedu.2009.06.011

Pintrich, P. R. (2003). A motivational science perspective on the role of student motivation in learning and teaching contexts. Journal of Educational Psychology, 95(4), 667-686. doi:10.1037/0022-0663.95.4.667

Raab, R. T., Ellis, W. W., \& Abdon, B. R. (2002). Multisectoral partnerships in e-learning A potential force for improved human capital development in the Asia Pacific. The Internet and Higher Education, 4(3-4), $217-229$. doi:10.1016/S1096-7516(01)00067-7

Ryan, R. M., \& Deci, E. L. (2000). Intrinsic and extrinsic motivations: Classic definitions and new directions. Contemporary Educational Psychology, 25(1), 54-67. doi:10.1006/ceps.1999.1020 PMID:10620381

Sharma, D., \& Kumar, V. (2017). A Framework for Collaborative and Convenient Learning on Cloud Computing Platforms. International Journal of Web-Based Learning and Teaching Technologies, 12(2), 1-20. doi:10.4018/ IJWLTT.2017040101

Shibi, B., Kadiri, K., \& Aknin, N. (2013). Towards collaborative learning process based on hybrid cloud computing and Web 2.0 tools. International Journal of Engineering and Technology, 5(3).

Shuangquan, H. (2010). On Design Strategy of the Collaborative Learning Activities under Cloud Computing Assisted Instruction. Educational Technology and Equipment in China, 36, 142-144.

Siemens, G. (2005). Connectivism: A Learning Theory for the Digital Age. http://www. elearnspace. org

Singh, J., \& Kumar, V. (2014). Multi-Disciplinary Research Issues in Cloud Computing. Journal of Information Technology Research, 7(3), 32-53. doi:10.4018/jitr.2014070103

Vallerand, R. J. (2000). Deci and Ryan's self-determination theory: A view from the hierarchical model of intrinsic and extrinsic motivation. Psychological Inquiry, 11(4), 312-318.

Welsh, E. T., Wanberg, C. R., Brown, K. G., \& Simmering, M. J. (2003). E-learning: Emerging uses, empirical results and future directions. International Journal of Training and Development, 7(4), 245-258. doi:10.1046/ j.1360-3736.2003.00184.x

Vikas Kumar received M Sc. in Electronics from Kurukshetra University, Haryana, India. This was followed by M Sc in Computer Science and further Ph. D. from the same university. He is a life member of Indian Science Congress Association, Computer Society of India, IETE, ICEIE, IPA, VEDA, IVS and Magnetic Society of India. Dr. Kumar has designed and conducted number of training programs for the corporate sector and is a trainer for a number of Govt of India departments. Along with 11 books, He has more than 100 research papers to his credit in various national and international conferences and journals. Out of which,53 are with the scopus indexed international journals. He was the Editor of International Quarterly Refereed Journal "Asia-Pacific Business Review" during June 2007-June 2009.Dr. Kumar is serving as a Professor at the Chaudhary Bansi Lal University, Bhiwani, India and is a visiting Professor at the Indian Institute of Management, Indore and University of Northern Iowa, USA. 